https://doi.org/10.37208/tgn27121

\section{The caddisfly Adicella filicornis (Trichoptera: Leptoceridae) in Scotland}

\author{
C.R. Macadam ${ }^{1}$, A. Dixon \& S. Crofts \\ ${ }^{1}$ Buglife - The Invertebrate Conservation Trust, \\ Balallan House, 24 Allan Park, Stirling FK8 2QG \\ E-mail: craig.macadam@buglife.org.uk
}

The caddisfly Adicella filicornis (Pictet, 1834) is associated with very small trickles or seepages of water, close to their origin from groundwater springs. These habitats typically have an unstable bed and are almost always in areas with steep slopes. It was first discovered in Great Britain by Kenneth Morton during an excursion to Cleghorn Glen near Lanark, South Lanarkshire with the Glasgow Natural History Society in June 1883 (Morton, 1884), and to date this remains the only Scottish site for this species, with only five other extant populations in South Devon, Monmouthshire, Merionethshire, Denbighshire (Wallace, 2016), and Yorkshire where it was recently rediscovered by Andrew Dixon. Wallace (1976) rediscovered A. filicornis at Cleghorn Glen in February 1971 by searching for larvae in the type of habitat described by Morton. However, searches in 2012 did not find the species (Kirkland et al., 2012).

Cleghorn Glen is an area of ancient woodland in a gorge formed by the Mouse Water, a tributary of the River Clyde. The underlying geology is limestone with old red sandstone. The slopes of the gorge are dominated by mixed ash woodland comprising ash, elm, sycamore and hazel, with alder in wetter areas. Several watercourses flow from the north down the slope of the gorge to join the Mouse Water. An area of groundwater seepage in Cleghorn Glen at NS8976545713 was visited on the 29th August 2018 to determine whether A. filicornis was still present. The seepage was in a small clearing and measured approximately $15 \mathrm{~m}$ x $5 \mathrm{~m}$. Abundant creeping buttercup (Ranunculus repens) was present across the seepage together with smaller patches of silverweed (Argentina anserina). Adult caddisflies were collected by sweeping vegetation and larvae were collected by scooping small quantities of silt into a tub and using a "panning" action to reveal heavier caddis larvae and their cases.

Eight species of caddisfly and one species of stonefly were recorded. A single larval specimen of A. filicornis (Fig. 1) was collected from the outflow of the seepage, together with three other caddisfly species and a stonefly associated with springs and trickles: Crunoecia irrorata (Curtis, 1834), Beraea maurus (Curtis, 1834),
Wormaldia occipitalis (Pictet, 1834), and the stonefly Nemurella pictetii (Klapálek, 1900). Also present were larvae of Lepidostoma hirtum (Fabricius, 1775), Hydropsyche siltalai Doehler, 1963, Potamophylax latipennis (Curtis, 1834), and Plectrocnemia conspersa (Curtis, 1834). Two adults of Diplectrona felix McLachlan, 1878 were collected close to the seepage, although no larvae were collected.

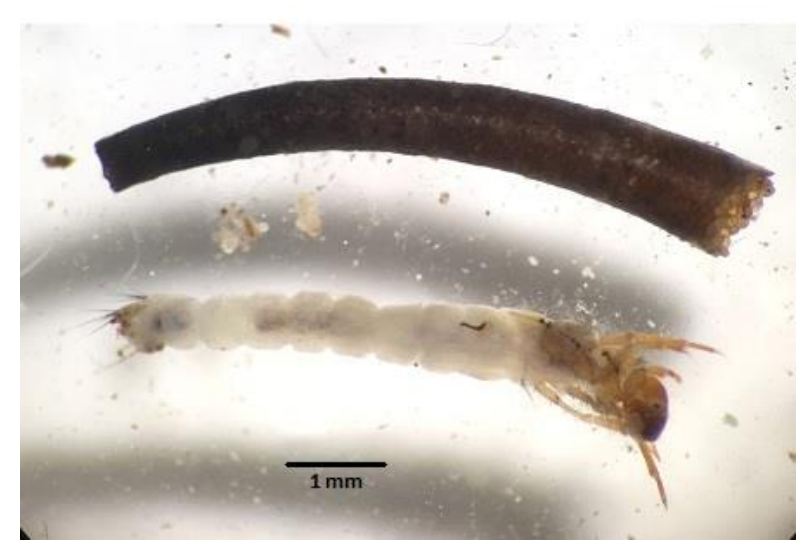

Fig. 1. Larva and case of the caddisfly Adicella filicornis found at Cleghorn Glen near Lanark, South Lanarkshire, Scotland on 29th August 2018. (Photo: C.R. Macadam)

This survey has confirmed the continued presence of A. filicornis at its only Scottish site. The area occupied in Cleghorn Glen is very small and as a result this population could be at risk from damage to the physical habitat where it lives. Future management of the site should avoid any changes to the habitat and conditions in the area. There are a number of other wooded gorges in the Clyde Valley, for example Nethan Gorge, Garrion Gill, and around the Falls of Clyde, that should be searched for this species.

\section{ACKNOWLEDGEMENT}

The authors would like to thank Kerry Wallace from Scottish Natural Heritage for permission to sample the site.

\section{REFERENCES}

Kirkland, P., Cathrine, C., Bairner, S., Macadam, C. \& Willet, J. (2012). Site Condition Monitoring of Invertebrate Assemblages at Ten Designated Sites in Scotland. Unpublished report by Caledonian Conservation Ltd. for Scottish Natural Heritage.

Morton, K.J. (1884). Adicella filicornis, Pict.; an addition to the British Trichoptera. Entomologist's Monthly Magazine 21, 91.

Wallace, I.D. (1976). The Taxonomy of Larvae of the British Species of the Family Leptoceridae (Trichoptera), with Notes on their General Biology. Ph.D. Thesis, University of Newcastle upon Tyne.

Wallace, I.D. (2016). A Review of the Status of the Caddis Flies (Trichoptera) of Great Britain. Species Status No. 27. Natural England Commissioned Report, NECR191. 